\title{
AKSELERASI:
}

JURNAL PENDIDIKAN GURU MI

Volume 2, Nomor 2, Desember 2021, Hal. 69-78

\section{PENGELOLAAN PENDIDIKAN KARAKTER DI MADRASAH IBTIDAIYAH NAHDLATUL ULAMA PADA MASA PANDEMI COVID-19}

\author{
Rofiqoh Firdausi ${ }^{1,}$ Nanik Ulfa ${ }^{2}$ \\ ${ }^{1}$ Prodi PGMI Fakultas Ilmu Kesilaman, Universitas Islam Raden Rahmat Malang \\ e-mail: rofiqoh.firdausi@uniramalang.ac.id \\ ${ }^{2}$ Prodi PGMI Fakultas Ilmu Kesilaman, Universitas Islam Raden Rahmat Malang \\ e-mail: nanikulfaunira@gmail.com
}

\begin{abstract}
Character education in madrasah is important to be developed continuously. Madrasah as formal educational institutions are the ideal generation of the nation. The teacher has a very strategic position in building the character of students. In order for the management of character education in madrasah to be optimal, effective and efficient, effective and efficient management activities are needed as well. Character education is very important for students. Therefore, even though currently during the Covid-19 pandemic, character education must still be conveyed to students. The purpose of this study is to analyze the character education management in madrasas during the pandemic. This research uses a descriptive analysis method with a qualitative approach and library data sources. The results of this study are that the character education management in madrasas during the pandemic can be implemented by: First, collaboration between madrasas and parents of students must be continuously woven, strengthened, and increased in intensity and quality. Second, the use of information and communication technology (ICT) is an instrument for learning value based on character, and can be used as best as possible to develop the attitudes of students. The third Problem Based Learning (PBL) builds a sense of responsibility and makes students not easily bored in online learning because it builds motivation in obtaining solutions to the problems at hand.
\end{abstract}

Keywords: character education, covid-19 pandemic

\begin{abstract}
ABSTRAK
Pendidikan karakter di madrasah penting untuk dikembangkan secara terus-menerus. Madrasah sebagai lembaga pendidikan formal merupakan pencetak generasi bangsa yang ideal. Guru memiliki posisi yang sangat strategis dalam membangun karakter peserta didik. Agar pengelolaan pendidikan karakter di madrasah dapat optimal, efektif, dan efisien, maka diperlukan kegiatan manajemen yang efektif dan efisien pula. Pendidikan karakter sangat penting bagi peserta didik. Oleh karena itu meskipun sekarang ini dalam masa pandemi Covid-19 pendidikan karakter tetap harus tersampaikan ke peserta didik. Tujuan penelitian ini yaitu untuk menganalisis pengelolaan pendidikan karakter di madrasah pada masa pandemi. Penelitian ini menggunakan metode analisis deskriptif dengan pendekatan kualitatif dan sumber data kepustakaan. Hasil penelitian ini adalah bahwa pengelolaan pendidikan karakter di madrasah pada masa pandemi dapat dilaksanakan dengan cara: Pertama kolaborasi antara madrasah dengan orang tua siswa harus terus-menerus dijalin, dipererat, dan ditingkatkan intensitas dan kualitasnya. Kedua pemanfaatan teknologi informasi dan komunikasi (TIK) sebagai sarana untuk pembelajaran nili-nilai dasar pendidikan karakter, dan dapat dimanfaatkan sebaik-baiknya untuk mengembangkan
\end{abstract}


kreativitas peserta didik. Ketiga Problem Based Learning (PBL) membangun rasa tanggung jawabdan menjadikan siswa tidak mudah jenuh dalam belajar online karena terbangun motivasi dalam memperoleh pemecahan masalah yang dihadapi.

Kata Kunci: pengelolaan, pendidikan karakter, pandemi covid-19

\section{PENDAHULUAN}

Pendidikan merupakan suatu proses dalam mengembangkan diri tiap individu untuk dapathidup dan melangsungkan kehidupan. Peserta didik agar menjadi orang yang berguna baik baginegara, nusa dan bangsa. Bangsa Indonesia tidak hanya meletakkan pendidikan sebagai sesuatu yang penting, tetapi bangsa Indonesia berusaha merealisasikan konsep pendidikan dengan cara pembinaan, pelatihan dan pemberdayaan sumber daya manusia (SDM) Indonesia secara berkelanjutan dan merata. Undang-undang No.20 tahun 2003 tentang Sisdiknas yang menyatakan bahwa tujuan pendidikan adalah agar menjadi manusia yang beriman dan bertakwa kepada Tuhan Yang Maha Esa, berakhlak mulia, sehat, berilmu, cakap, kreatif, mandiri, dan menjadi warga negara yang demokratis serta bertanggung jawab. ${ }^{1}$

Ketersediaan sumber daya manusia yang berkarakter merupakan kebutuhan yang amat urgen. Hal ini dilakukan untuk mempersiapkan tantangan global dan daya saing bangsa. Pendidikan karakter dipengaruhi oleh faktor yang sangat kompleks mulai dari pendidikan dalam keluarga, lingkungan tempat tinggal, dan pendidikan dimadrasah.

Untuk mencapai hasil yang maksimal, pendidikan karakter di Madrasah ibtidaiyah Nahdlatul Ulama penting untuk dikembangkan secara terus-menerus. Karena madrasah sebagai lembaga pendidikan formal merupakan pencetak generasi bangsa yang ideal. Dalam pengelolaan pendidikan karakter di madrasah, semua komponen (stakeholders) terlibat. Komponen-komponen pendidikan yaitu isi kurikulum, proses pembelajaran dan penilaian, kualitas hubungan, penanganan atau pengelolaan mata pelajaran, pengelolaan madrasah, pelaksanaan aktivitas, pemberdayaan sarana prasarana, pembiayaan, dan etos kerja seluruh warga dan lingkungan madrasah. Agar pengelolaan pendidikan karakter di madrasah dapat optimal, efektif, dan efisien maka diperlukan kegiatan manajemen yang efektif dan efisien pula.

Pendidikan karakter di madrasah juga erat kaitannya dengan pengelolaan madrasah. Pengelolaan di sini mencakup fungsi manajemen pendidikan karakter mulai dari perencanaan, pengorganisasian, pelaksanaan, dan pengendalian atau evaluasinya. Dengan demikian, manajemen madrasah merupakan proses yang efektif dalam pendidikan karakter dimadrasah.

Pendidikan karakter sangat penting bagi peserta didik. Oleh karena itu meskipun sekarang ini dalam masa pandemi Covid-19 pendidikan karakter tetap harus tersampaikan ke peserta didik. Berkaitan dengan pembelajaran pada masa pandemi ini, Mendikbud Nadim Anwar

\footnotetext{
${ }^{1}$ Undang undang No. 20 tentang Sisdiknas tahun (2003) Jakarta:PT. Armas Duta Jaya
} 
Makarim menerbitkan Surat Edaran Nomor 4 Tahun 2020 tentang Pelaksanaan Pendidikan Dalam Terkait belajar dari rumah pada masa darurat Corona Virus Disease (Covid-19), Mendikbud menekankan bahwa pembelajaran dalam jaringan (daring) atau jarak jauh dilaksanakan untuk memberikan pengalaman belajar yang bermakna bagi siswa, tanpa terbebani tuntutan menuntaskan seluruh capaian kurikulum untuk kenaikan kelas maupun kelulusan. Mendikbud menganjurkan bagi daerah yang sudah melakukan belajar dari rumah agar dipastikan guru juga mengajar.

\section{METODE}

Penelitian ini menggunakan metode analisis deskriptif. Penelitian ini mendeskripsikan tentang pengelolaan pendidikan karakter pada masa pandemi Covid-19 di Lembaga MI Nahdlatul ulama Kemulan Kecamatan Turen Kabupaten Malang. Penelitian ini menggunakan sumber data sekunder, diantaranya adalah laman, jurnal, dan buku-buku yang berkaitan dengan pendidikan karakter. Pendekatan yang digunakan dalam penelitian ini adalah kualitatif. Analisis data kualitatif ini terdiri dari beberapa alur kegiatan yaitu kategorisasi, reduksi data, penyajian data dan penarikan kesimpulan.

\section{HASIL DAN PEMBAHASAN}

Dalam Panduan Pelaksanaan Pendidikan Karakter, pendidikan karakter adalah pendidikan nilai, pendidikan budi pekerti, pendidikan moral, pendidikan watak yang bertujuan mengembangkan kemampuan seluruh warga madrasah untuk memberikan keputusan baikburuk, keteladanan, memelihara apa yang baik dan mewujudkan kebaikan itu dalam kehidupan sehari-hari dengan sepenuh hati.

Sebagaimana yang dijelaskan Hakam, pendidikan nilai adalah pendidikan yang mempertimbangkan objek dari sudut pandang moral yang meliputi etika dan norma-norma yang meliputi estetika, yaitu menilai objek dari sudut pandang keindahan dan selera pribadi, serta etika yaitu menilai benar/salahnya dalam hubungan antar pribadi. Tujuan pendidikan nilai menurut Suparno, adalah menjadikan manusia berbudi pekerti. Mulyana dan Hakam menambahkan bahwa pendidikan nilai bertujuan untuk membantu peserta didik mengalami dan menempatkan nilai-nilai secara integral dalam kehidupan mereka. ${ }^{2}$

Pendidikan memegang peranan penting dalam membentuk akhlak mulia dan luhur bagi peserta didik. Keberhasilan dalam pendidikan karakter sendiri dipengaruhi oleh berbagai faktor, seperti cara atau pendekatan yang dipergunakan dalam menyampaikannya. Menurut Suparno, dkk ada empat model pendekatan penyampaian pendidikan karakter, yaitu: 1) Model sebagai mata pelajaran tersendiri (monolitik), dimana pendidikan karakter dianggap sebagai mata pelajaran tersendiri. 2) Model terintegrasi dalam semua mata pelajaran, yaitu dalam menyampaikan pendidikan karakter adalah disampaikan secara terintegrasi dalam setiap bidang

\footnotetext{
${ }^{2}$ Hakam, K. A. (2005). Pendidikan Nilai. Bandung: CV Maulana
} 
pelajaran, dan oleh karena itu menjadi tanggunmg jawab semua guru. 3) Model di luar pengajaran, yang lebih mengutamakan pengolahan dan penanaman nilai melalui suatu kegiatan untuk dibahas dan kemudian dibahas nilai-nilai hidupnya. 4) Model gabungan, adalah menggabungkan antara model terintegrasi dan model di luar pelajaran secarabersama.

Pada masa pandemi, pendidikan di Indonesia beralih melalui daring (online). Hampir semua jenjang mengikuti pembelajaran melalui platform yang terdapat di komputer. Banyak pembelajaran yang diambil ketika mengikuti belajar online. Keberadaan madrasah penting untuk membuka wawasan tentang pendidikan karakter melalui pendidikan jarak jauh, dengan membekali keterampilan guru dalam pelaksanaan pembentukan karakter melalui pendidikan jarak jauh. Dengan demikian madrasah dan konselor memegang peranan penting dalam menumbuhkan keteladanan nilai-nilai karakter khususnya pada masa belajar di rumah, menginspirasi guru dengan berbagai strategi yang dapat diterapkan madrasah dalam pembentukan karakter.

Pengelolaan pendidikan karakter dapat dikembangkan melalui habituasi yaitu dengan cara diajarkan, dibiasakan, dilatih konsisten, menjadi kebiasaan, menjadi karakter, menjadi budaya. Pelaksanaan ini dapat diterapkan mulai dari rumah, kelas, madrasah, dan masyarakat. Diantara pengembangan pengelolaan pendidikan karakter masa pandemi dapat diimplementasikan dengan cara sebagai berikut:

1. Kolaborasi antara Madrasah dengan Orang TuaSiswa

Hasil penelitian Takhroji Aji terhadap orang tua murid dari tingkat TK sampai dengan SMU menunjukan orang tua siswa setuju bahwa mereka tidak dapat sepenuhnya melakukan pendidikan karakter terhadap anaknya tanpa bantuan guru. Para orang tua yakin bahwa guru sangat membantu mereka dalam membentuk dan membangun karakter anakanaknya. Mereka merasa bahwa keberadaan guru dalam membangun karakter anak-anak sangat dibutuhkan. Tanpa adanya peran serta guru maka orang tua tidak dapat secara maksimal membentuk dan membangun karakter anak-anak mereka.

Dari hasil penelitian diperoleh data sebagai berikut: dari 178 responden, 92,1\% (164 responden) menyatakan bahwa orang tua tidak dapat membangun karakter anak dengan maksimal tanpa peran serta para guru. Kemudian 157 responden dari 178 responden $(88,2 \%)$ menyatakan bahwa karakter anak tidak dapat dibangun di rumah dan lingkungan anak tanpa adanya peran serta madrasah.

Dari penelitian penulis tersebut dapat diambil kesimpulan bahwa penting bagi guru untuk bekerja sama dengan orang tua siswa dalam melaksanakan pendidikan karakter terhadap siswa. Orang tua siswa membutuhkan panduan dan arahan dari guru dalam pendidikan karakter untuk anak-anak mereka.Setiap mata pelajaran selalu ada bagian karakter yang harus dikembangkan. Pihak madrasah memberikan informasi tentang nilai- 
nilai karakter yang akan ditanamkan. Pendidikan karakter yang diintegrasikan dalam pembelajaran berbagai bidang studi dapat memberikan pengalaman yang bermakna bagi siswa.

Belajar dari pandemi, guru, orang tua dan masyarakat harus bersinergi gotong royong membangun pendidikan. Selain itu, peran guru saat ini yang digantikan orang tua adalah membimbing keteraturan dan kedisiplinan ketika proses belajar, juga memotivasi anak dalam belajar dan menjadi fasilitator yang baik bagi anak dalam belajar. Masa pandemi ini menjadikan pendidikan yang pertama dan utama adalah di rumah. Dalam hal ini madrasah mengambil peran sebagai fasilitator.

Keluarga merupakan kelompok sosial yang pertama dalam kehidupan manusia, tempat pertama dalam belajar dan menyatakan diri sebagai manusia sosial di dalam hubungan interaksi dengan kelompoknya. Pengaruh dominan yaitu distorsi terhadap waktu penjadualan kegiatan pembelajaran peserta didik, baik secara struktur, pembagian tugas dan internalisasi norma-norma. Peran yang selama ini dilaksanakan di satuan pendidikan beralih fungsi di satuan keluarga.

Kemandirian anak harus ditumbuhkan, harus ada peran dominan orang tua dalam mendidik siswa, khususnya pada pendidikan karakter. Salah satu yang harus dikembangkan adalah kemandirian. Membuat anak mandiri itu jauh lebih berharga dan bisa menjadi alat untuk berkreativitas. Karena itulah dibutuhkan peran serta orang tua dan guru agar dapat menumbuhkan karakter siswa yang kuat dan tangguh.Dengan demikian kerja sama antara pihak madrasah dan orang tua siswa harus terus-menerus dijalin, dipererat, dan ditingkatkan intensitas dan kualitasnya. Orang tua siswa memiliki fasilitator atau pemandu dalam mendampingi anaknya dalam pembelajaran di rumah terutama dalam membangun karakter anak. Hal tersebut membantu orang tua siswa mempermudah langkah langkah yang harus diterapkan terhadap anaknya.

2. Pemanfaatan Teknologi Informasi dan Komunikasi(TIK)

Pandemi Covid-19 menyebabkan penutupan madrasah-madrasah dalam upaya menghentikan pergerakkan pandemi. Sebagai gantinya, pemerintah telah memberlakukan sistem Pendidikan Jarak Jauh (PJJ). Sistem PJJ yang berbasis teknologi mengharuskan lembaga pendidikan, guru, siswa bahkan orang tua agar cakap teknologi. Hal ini berdampak positif yaitu memicu percepatan transformasi teknologi pendidikan di negeri ini. Penggunaan TIK dalam pendidikan selaras dengan era Revolusi Industri 4.0 yang terus bergerak maju. Percepatan transformasi teknologi pendidikan karena pandemi Corona membuat berbagai platform meluncurkan berbagai aplikasi belajar online guna mendukung PJJ.

Penggunaan TIK di Indonesia memasuki tahap mempelajari berbagai kemungkinan 
untuk pengembangan dan penerapan teknologi untuk pendidikan. Informasi yang diwakili oleh komputer yang terhubung ke internet sebagai media utama telah mampu memberikan kontribusi yang begitu besar bagi proses pendidikan. Selama masa pandemi ini, banyak hikmah yang bermanfaat terutama dalam hal penggunaan teknologi. Semua pihak di sektor pendidikan harus menyadari peranan penting teknologi dalam mendukungpembelajaran.

Banyak munculnya aplikasi belajar online membuat belajar tetap dapat dilakukan dengan efektif. Aplikasi-aplikasi belajar online dikembangkan dengan penyediaan fiturfitur yang memudahkan dalam melakoni belajaronline.

Dalam pengembangan pengelolaan pendidikan karakter harus keluar dari zona nyaman untuk berinovasi menciptakan kreativitas, harus melakukan adaptasi yang lebih dengan penggunaan media teknologi. Peran guru yang dapat dilakukan saat pembelajaran di rumah adalah menyiapkan materi pembelajaran, mengajarkan dan mengevaluasi pembelajaran. Penting bagi guru untuk meningkatkan kreativitas untuk pembelajaran di rumah agar tidak terlalu bosan.

Dengan pembelajaran jarak jauh menuntut semua pihak baik guru maupun siswa dapat beradaptasi terutama dengan media elektronik sebagai alat pembelajaran. Sisi positif dari kondisi ini mendorong guru dan siswa memiliki kecakapan personal bidang teknologi informasi dan komunikasi. Hakikat kecakapan personal (personal skill) dalam konsepsi ini merupakan kecakapan diri yangdiperlukanolehindividuagarseseorangdapateksisdanmampumengambilpeluangyangposi tif dalam kondisi kehidupan yang berubah dengan sangat cepat.

Dalam rangka pembangunan sumberdaya manusia yang berkualitas, bermartabat, dan berkarakter, pemanfaatan TIK perlu dijaga agar tidak mengganggu pembentukan karakter peserta didik, melainkan justru mendukungnya. Dengan demikian pemanfaatan TIK dalam pendidikan perlu direncanakan, dilaksanakan, dan dievaluasi secara berkelanjutan.

Menurut Heri gunawan ${ }^{3}$,untuk menjaga agar pemanfaatan TIK tetap memberikan kontribusi signifikan terhadap; pengembangan peserta didik menjadi manusia berkarakter dan berkecerdasan intelektual; dan pemberdayaan pendidik dan tenaga kependidikan terkait, hendaknya diterapkan prinsip-prinsip berikut: a) Pemanfaatan TIK dalam pendidikan sebaiknya mempertimbangkan karaktersitik peserta didik, pendidik, dan tenaga kependidikan dalam keseluruhan pembuatan keputusan TIK, b) Pemanfaatan TIK sebaiknya dirancang untuk memperkuat minat dan motivasipengguna untuk menggunakannya semata guna meningkatkan dirinya, baik dari segi intelektual, spiritual (rohani), sosial, maupun ragawi, c) Pemanfaatan TIK sebaiknya menumbuhkan kesadaran dan keyakinan akan

\footnotetext{
${ }^{3}$ Gunawan, Heri. (2014).Pendidikan Karakter, Konsep dan Implementasi, Bandung: Alfabeta.
} 
pentingnya kegiatan berinteraksi langsung dengan manusia (tatap muka),dengan lingkungan sosial-budaya (pertemuan, museum, tempat-tempat bersejarah), dan lingkungan alam (penjelajahan) agar tetap mampu memelihara nilai-nilai sosial dan humaniora (seni dan budaya), dan kecintaan terhadap alam sebagai anugerah dari Tuhan Yang Maha Esa, d) Pemanfaatan TIK sebaiknya menjaga bahwa kelompok sasaran tetap dapat mengapresiasi teknologi komunikasi yang sederhana dan kegiatan-kegiatan pembelajaran tanpa TIK karena tuntutan penguasaan kompetensi terkait dalam rangka mengembangkan seluruh potensi siswa secara seimbang, e) Pemanfaatan TIK sebaiknya mendorong pengguna untuk menjadi lebih kreatif dan inovatif sehingga tidak hanya puas menjadi konsumen informasi berbasis TIK.

Guru hendaknya dalam menyampaikan materi dengan metode yang menarik dan interaktif sehingga dapat menstimulus kreatifitas siswa. Hal itu menjadikan implementasi pendidikan karakter melalui TIK mencapai tujuan. Guru sebagai fasilitator. Pembelajaran lebih berpusat pada peserta didik bukan pada guru. Proses pelaksanaan pembelajaran melalui TIK, peserta didik selain diarahkan mencari dan memperoleh informasi juga diarahkan agar memiliki kemampuan untuk menciptakan dan memberikan informasi di internet dengan berbagai karya baik bentuk tulisan atau video. Dengan demikian kreatifitas siswa akan tergali danteroptimalkan.

Untuk tercapainya hal di atas guru dapat memberikan teladan dengan membuat konten-konten pembelajaran melalui blog dan video platform seperti youtube dan sebagainya. Yang demikian ini banyak memberikan manfaat bagi siswa karena materi dapat dilihat berulangkali. Sehingga pesan nilai yang terkandung di dalam materi pembelajaran lebih mungkin terserap oleh siswa. Dengan melihat keteladanan yang didapat dari gurunya dalam pemanfatan TIK dalam pembelajaran, peserta didik pun akan terbiasa dan mengikuti dalam pemanfaatan TIK. Pembiasaan tersebut merupakan pembinaan pendidikan budaya dan karakter yang terus dikembangkan oleh paragurudi MI Almuddatsir Kemulan Kecamatan Turen Kabupaten Malang.

Pembelajaran melalui TIK akan melatih peserta didik mampu mendengar, berbicara, membaca, dan menulis dengan baik. Keterampilan tersebut sangat bermanfaat, mampu menyampaikan pesan kepada masyarakat secara luas. TIK sebagai sarana untuk pembelajaran nilai-nilai dasar pendidikan karakter, dan dapat dimanfaatkan sebaik-baiknya untuk mengembangkan kreativitas peserta didik.

3. Problem Based Learning(PBL)

Pengertian Problem Based Learning (PBL) ${ }^{4}$ didasarkan pada teori psikologi kognitif

\footnotetext{
${ }^{4}$ Fuadi, Ahmad Sahal. (2020)Penerapan Model Pembelajaran Problem Based Learning (PBL) Pada Masa Pandemi Covid 19
} 
terutama berlandaskan teori Piaget dan Vigotsky (konstruktivisme). Bahwa peserta didik belajar mengkonstruksi pengetahuannya melalui interaksi dengan lingkungannya. Problem Based Learning (PBL) dapat membuat siswa belajar melalui upaya penyelesaian masalah dunia nyata (real world problem) secara terstruktur untuk mengonstruksi penegatahuan peserta didik. Pembelajaran ini menuntut peserta didik untuk aktif melakukan penyelidikan dalam menyelesaikan permasalahan dan pendidik berperan sebagai fasilitator atau pembimbing.

Melalui PBL melatih siswa menyusun sendiri pengetahuannya, mengembangkan keterampilan memecahkan masalah. Selain itu, dengan pemberian masalah autentik, siswa dapat membentuk makna dari bahan pelajaran dengan proses belajar dan menyimpannya dalam ingatan sehingga suatu saat dapat digunakan lagi. Jadi Problem Based Learning atau pembelajaran berbasis masalah adalah suatu strategi pembelajaran yang menjadikan masalah dunia nyata sebagai suatu konteks bagi peserta didik untuk belajar tentang cara berpikir kritis dan keterampilan dalam memecahan masalah, serta untuk mendapatkan pengetahuan dan konsep yang esensial dari materipelajaran.

Dibangunnya pemikiran dasar pembelajaran dengan penerapan Problem Based Learning adalah untuk menyelesaikan masalah. Dengan demikian orang yang memiliki kemauan tinggi untuk menyelesaikan masalah termasuk orang yang bertanggung jawab. Dan tanggung jawab itu adalah nilai dari sebuah karakter. Sehingga Problem Based Learning memiliki karakter utama yaitu tanggung jawab.

Nilai karakter tanggung jawab ini menjadi gerbang untuk membuka nilai-nilai karakter lainnya apabila diterapkan dalam pembelajaran. Karena Problem Based Learning yang masih asli hanya mengandung satu nilai karakter secara implisit, maka perlu pengembangan Problem Based Learning secara lebih kompleks. Dengan demikian pengembangan Problem Based Learning akan mengembangkan hal-hal di bawah ini.

Pertama, Problem Based Learning dikaji dan digali untuk diaktualisasikan dalam pembelajaran, sehingga nilai-nilai karakter tersebut dapt ditanamkan atau diinternalisasikan ke dalam diri peserta didik. Dalam hal ini, Problem Based Learning dianggap seolah-olah telah ada atau mengandung muatan nilai karakter di dalamnya.

Kedua, Problem Based Learning dapat dimodifikasi dan dikembangkan secara kreatif agar memuat nilai-nilai karakter lebih kompleks. Artinya, Problem Based Learning dapat diisi muatan nilai karakter dari luar yang sesuai kepentingan pendidik dalam pembelajaran. Dalam hal ini, ProblemBased Learning diperlukan sebagai strategi pembelajran yang netral sehingga dapat diisi dengan muatan nilai-nilai karakter sesuai kepentingan pendidik dan peserta didik.

Problem Based Learning juga merupakan suatu pembelajaran yang melibatkan 
peserta didik untuk memecahkan suatu masalah melalui tahap-tahap metode ilmiah. Peserta didik dapat mempelajari pengetahuan yang berhubungan dengan masalah tersebut sekaligus memiliki keterampilan untuk memecahkan masalah.Cara mencapai hasil pembelajaran secara optimal, pembelajaran berbasis masalah perlu dirancang dengan baik mulai dari penyiapan masalah yang sesuai dengan kurikulum yang dikembangkan dikelas,memunculkan masalah dari peserta didik, peralatan yang mungkin diperlukan, dan penilaian yang digunakan. Pengajar yang menerapkan ini harus mengembangkan diri melalui pengalaman mengelola dikelasnya, melalui pendidikan pelatihan atau pendidikan formal yangberkelanjutan.

Dengan demikian pendidikan karakter melalui PBL pada masa pandemi sangat strategis. Siswa tidak mudah jenuh karena terbangun tanggung jawab dan motivasi dalam memperoleh pemecahan masalah yangdihadapidi MI Almuddatsir Kemulan Kecamatan Turen Kabupaten Malang.

\section{KESIMPULAN DAN SARAN}

Madrasah merupakan lembaga yang efektif sebagai tempat untuk mencetak generasi penerus yang berkarakter ideal. Tetapi pada masa pandemi Covid-19 sekarang ini dalam menjalankan perannya madrasah mengalami kendala dan hambatan. Pendidikan madrasah dilaksanakan secara jarak jauh. Guru tidak dapat berinteraksi dengan siswa secara langsung. Maka pengelolaan pendidikan karakter di madrasah pada masa pandemi dapat dilaksanakan dengan cara: Pertama, kolaborasi antara madrasah dengan orang tua siswa harus terus-menerus dijalin, dipererat, dan ditingkatkan intensitas dan kualitasnya. Kedua, pemanfaatan teknologi informasi dan komunikasi (TIK) sebagai sarana untuk pembelajaran nili-nilai dasar pendidikan karakter, dan dapat dimanfaatkan sebaik-baiknya untuk mengembangkan kreativitas peserta didik. Ketiga, penerapan Problem Based Learning (PBL) dapat membangun rasa tanggung jawab dan menjadikan siswa tidak mudah jenuh dalam belajar online karena terbangun motivasi dalam memperoleh pemecahan masalah yang dihadapi.

Dalam penelitian ini fokus pada pengelolaan pendidikan karakter di MI Almuddatsir Kemulan Kecamatan Turen Kabupaten Malang pada masa pandemi. Selanjutnya para peneliti berikutnya dapat melakukan penelitian tentang evaluasi terhadap pelaksanaan pendidikan karakter pada pasa pandemi.

\section{DAFTAR PUSTAKA}

Adit, Albertus. (2020). https://www.kompas.com/edu/read/2020/07/06/134752871/di-masapandemi-orangtua-berperan-dalam-pendidikan-karakter-anak. Diakses 15Juli 2020.

Aji, Takhroji. (2020). https://bdkjakarta.kemenag.go.id/berita/pendidikan-karakter-di-masa- 
pandemi-menjadi-tanggung-jawab-siapa? Diakses 14 Juli 2020.

Fuadi, Ahmad Sahal. (2020)Penerapan Model Pembelajaran Problem Based Learning (PBL) Pada Masa Pandemi Covid 19 Dalam Meningkatkan Aktivitas Dan Hasil Belajar Siswa Pada Mata Pelajaran Produk Kreatif Dan Kewirausahaan. Seminar Nasional Manajemen, Ekonomi dan Akuntasi Fakultas Ekonomi dan Bisnis UNP Kediri 19 September 2020.

Gafuri, H. Akhmad. (2016).Pengembangan Model Manajemen Pendidikan Karakter Dengan Teknik Pendampingan Guru Pada Sekolah Dasar.Jurnal Paradigma, Volume 11, Nomor 2, Juli2016.

Gunawan, Heri. (2014).Pendidikan Karakter, Konsep dan Implementasi, Bandung: Alfabeta.

Hakam, K. A. (2005). Pendidikan Nilai. Bandung: CV Maulana.

Kementerian Pendidikan Nasional. (2011). Panduan Pelaksanaan Pendidikan Karakter.Jakarta: Pusat Kurikulum dan Perbukuan.

Kuswandi, Yudi dan Emma Himayaturohmah. (2018).Pembudayaan Nilai-Nilai Islami Dalam Membangun Karakter Bangsa(Studi Kasus di Sekolah Menengah Kejuruan Negeri 1 Cimahi).Tatar Pasundan: Jurnal Diklat Keagamaan Bandung. Vol. 12 (34)2018.

Mulyana, R. (2004). Mengartikulasikan Pendidikan Nilai. Bandung: CV. Alfabeta.

Ramin. (2018).Karakteristik Pendidikan Karater Siswa Pada Jenjang Pendidikan Dasar. Tatar Pasundan: Jurnal Diklat Keagamaan. Vol. 12 (32) 2018.

Sani, Ridwan Abdullah.(2014).Pembelajaran Santifik untuk Implementasi Kurikulum 2013, Jakarta: Bumi Aksara.

Subarto. (2020).Momentum Keluarga Mengembangkan Kemampuan Belajar Peserta Didik Di Tengah Wabah Pandemi Covid-19. Adalah Jurnal Hukum dan Keadilan volume 4 nomor 12020.

Suparno. (2002). Keterampilan Dasar Menulis. Jakarta: Universitas Terbuka, Departemen Pendidikan Nasional.

Suyadi.(2015). StrategiPembelajaranPendidikan Karakter, Bandung: Remaja Rosdakarya,Cet.III.

Taufikin. (2017). Pembentukan Karakter Melalui Pembelajaran Problem Based Learning. Jurnal Thufula Volume 5 Nomor 1 Januari - Juni 2017.

Widoyoko, S. E. (2007). Pengembangan Model Evaluasi Pembelajaran IPS di SMP, Disertasi.Yogyakarta: PPS UNY.

Zuchdi, Darmiyati dkk. (2010). Pengembangan Model Pendidikan Karakter Terintegrasi Dalam Pembelajaran Bidang Studi Di Sekolah Dasar. Cakrawala Pendidikan Jurnal Ilmiah PendidikanNo. 3 Mei 2010

-- (2003). Undang-Undang Sistem Pendidikan Nasional. Jakarta: CV. Ekajaya. 